\title{
KETERKAITAN VARIASI PRODUK DAN TENAGA KERJA TERHADAP PENINGKATAN LABA BENGKEL AHAS PANDAAN
}

\author{
Muhamad Imam Syairozi
}

Fakultas Ekonomi, Universitas Islam Lamongan

Email: imamsyairozi@unisla.ac.id

\begin{abstract}
Penelitian ini dimaksudkan untuk mengidentifikasi pengaruh variasi dalam produk dan tenaga kerja untuk meningkatkan laba di AHASS Workshop Pandaan apakah mereka memiliki efek parsial, di mana variabel secara simultan dan lebih dominan, jenis penelitian kuantitatif yang dilakukan dengan metode penelitian uji validitas, reliabillity, asumsi klasik, regresi, koefisien determinasi, uji-t dan uji f. Metode pengumpulan data dilakukan dengan observasi, kuesioner dan dokumentasi. Dari hasil data di atas dapat disimpulkan data tersebut valid, dan ada hubungan yang dapat diandalkan secara parsial dan simultan, dan variabel yang paling dominan adalah variasi produk. Dari hasil regresi linier berganda yang berpengaruh dominan terhadap peningkatan pendapatan di AHASS Workhop Pandaan adalah variasi produk. Koefisien regresi variasi produk (X1) sebesar 0,563 berarti bahwa jika variasi produk meningkat sebesar satu unit maka pendapatan akan meningkat sebesar 0,563 dengan asumsi variabel lain memiliki pengaruh konstan.
\end{abstract}

Kata kunci-Variasi Produk, Tenaga Kerja dan Peningkatan Laba

This study was intended to identify the effect of variations in product and labor to increase profits at AHASS Workshop Pandaan whether theyhave a partial effect, where the variables simultaneously and more dominant, type of quantitative research conducted by validity test research methods, reliabillity, classical assumption, regression, coefficient of determination, $t$-test and $f$ test. Methods of data collection were done by observation, questionnaire and documentation. From the results of the above data it can be concluded the data is valid, and there is a relationship reliable partially and simultaneously, and the most dominant variable is a variation of products. From the results of multiple linear regression that affects predominantly to the increase in earnings in the AHASS Workhop Pandaan was a variation of products. Product Variations regression coefficient (X1) of 0.563 means that if variations product increased by one unit then the earnings will increase by 0.563 assuming that other variables held constant influence.

Keywords - Product Variations, Labor and Increasing Profit

(C) 2019 JBTI. All rights reserved

Article history : Received: 2019-10-14; Revised: 2019-10-22; Accepted: 2019-11-29

\section{PENDAHULUAN}

Perusahaan merupakan suatu organisasi yang mempunyai berbagai kegiatan tertentu dalam usaha untuk mencapai tujuan organisasi, yang pada umumnya bertujuan untuk menghasilkan laba yang optimal agar dapat mempertahankan kelangsungan hidup perusahaan, dan semaksimal mungkin tidak mengalami kerugian dalam kondisi perekonomian yang semakin meningkat, dan banyaknya perusahaan yang sama yang memproduksi barang sejenis sehingga menciptakan 
persaingan yang ketat. Perusahaan dituntut untuk memajukan serta mengembangkan usahanya ke tingkat yang lebih tinggi serta mempertahankan dan mengembangkan kualitas produksinya. Untuk mencapai keuntugan yang maksimal, maka salah satunya perlu kestabilan dari volume produk dan tenaga kerja dalam upaya peningkatan laba perusahaan. Dengan pemberian produk yang bervariatif dengan jaminan mutu kualitasnya, akan membuat harapan terhadap minat konsumen untuk membeli produk yang sedang diedarkan oleh produsen maupun distributor. Dengan produk yang bervariatif konsumen akan melakukan sebuah pembelian sehingga akan berdampak terhadap volume penjualan dan peningkatan laba. Dengan meningkatnya permintaan konsumen terhadap produk otomotif, membuat distributor berusaha untuk memenuhi kebutuhan yang konsumen inginkan. Pihak distributor akan berusaha memenuhi kebutuhan dan keinginan konsumen dengan meningkatkan variasi berbagai produk.

Disamping itu ketatnya persaingan antar perusahaan dalam era ekonomi global menuntut perusahaan untuk selalu menjadi terdepan dan terbaik dalam memberikan pelayanan yang memuaskan kepada konsumen. Persaingan yang terjadi merupakan suatu bagian yang tidak terpisahkan dari perusahaan, karena dengan adanya persaingan tersebut dapat menjadi salah satu pendorong dalam meningkatkan kinerja, serta dapat memberikan keuntungan positif bagi perusahaan dalam meningkatkan volume penjualan dan pangsa pasar sehingga mampu memenangkan persaingan di pasar. Salah satu strategi yang dapat digunakan perusahaan sebagai pendukung keberhasilan perusahaan yaitu tenaga kerja yang berkualitas.

Dalam hal ini tenaga kerja merupakan salah satu sumber daya manusia perusahaan yang cukup memiliki peranan dalam pencapaian tujuan perusahaan dalam peningkatan laba. Semakin efektif kegiatan atau aktivitas tenaga kerja, semakin tinggi kompetensi teknik tenaga kerja semakin tinggi pula presentase peningkatan laba yang dialami oleh perusahaan.

\section{TINJAUAN PUSTAKA}

Penelitian terdahulu dilakukan Rosdiyati yang berjudul Pengaruh Faktor Produksi Dan Biaya Tenaga Kerja Terhadap Laba Usaha Telur Asin UD. Sumber Rejeki Desa Tawangrejo Turi Kabupaten Lumajang. Dari hasil penelitian didapatkan koefisien korelasi parsial antara laba dan jumlah produk ketika variabel lainnya konstan adalah sangat kuat koefisien korelasi parsial antara laba dan biaya tenaga kerja adalah 0,977 . Variabel jumlah produk (X1) secara parsial mempunyai pengaruh signifikan terhadap laba (Y) dengan t hitung untuk variabel jumlah produk lebih besar dari t tabel yaitu sebesar 35,151> 2,00172. Variabel biaya tenaga kerja (X2) secara parsial mempunyai pengaruh signnifikan terhadap laba (Y) dengan t hitung untuk variabel biaya tenaga kerja lebih besar dari t tabel yaitu sebesar 32,390 > 2,00172. Variabel jumlah produk dan biaya tenaga kerja secara simultan berpengaruh signifikan terhadap laba dan $\mathrm{F}$ hitung lebih besar dari $\mathrm{F}$ tabel yaitu sebesar 729,135 > 3,16. Dengan demikian dapat disimpulkan bahwaterdapat hubungan yang erat antara variabel jumlah produk (X1) dan biaya tenaga kerja (X2) terhadap laba (Y). Menggunakan $\alpha=0,025$ dan jumlah produk mempunyai korelasi paling besar, sehingga hipotesis pada UD. Sumber Rejeki yang menyatakan bahwa variabel jumlah produk (X1) mempunyai pengaruh paling dominan dibandingkan dengan variabel biaya tenaga kerja (X2) terbukti.

Dalam penelitian ini yang berbeda dengan penelitian terdahulu selain lokasi, waktu, data penelitian juga variabel bebas (X1) dan (X2). Data penelitian terdahulu lebih kesektor produksi di USAHA TELUR ASIN sebagai objek sedangkan penelitian kali ini lebih ke sektor distribusi produk pada USAHA BENGKEL AHASS PANDAAN. Penelitian ini juga punya kesamaan yaitu menggunakan Variabel terikat (Y).

Penlitian sejenis dilakukan oleh Indra Nurrahman dan Rd.Dian Herdiana Utamayang berjudul Pengaruh Variasi Produk Terhadap Keputusan Pembelian Survei pada pembeli smartphone 
Nokia series $\mathrm{X}$ di BEC Bandung. Penelitian ini dilakukan untuk mengetahui gambaran dimensi variasi produk pembeli smartphone Nokia series X di BEC Bandung, mengetahui gambaran keputusan pembelian smartphone Nokia series X di BEC Bandung, mengetahui temuan mengenai seberapa besar pengaruh variasi produk terhadap keputusan pembelian pada pembeli smartphone Nokia series $X$ di BEC Bandung. Objek atau unit analisis smartphone Nokia series X di BEC Bandung. Variabel bebas (X) pada penelitian ini adalah variasi produk dan variabel terikat (Y) pada penelitian ini adalah keputusan pembelian. Jenis penelitian yang digunakan adalah deskriptif, verifikatif, dan metode yang digunakan explanatory survey dengan teknik yang digunakan systematic random samplin, dengan jumlah sampel sebanyak 100 pembeli. Teknik analisa data yang digunakan adalah path analysis dengan alat bantu software komputer SPSS 24.0. hasil yang diperoleh dalam penelitian menyatakan bahwa dimensi variasi produk berpengaruh secara simultan terhadap keputusan pembelian pada pembeli smartphone Nokia series X di BEC Bandung sebesar 63,5\%. Sedangkan pengaruh secara parsial menunjukkan bahwa dimensi ukuran memiliki pengaruh yang lebih besar dibandingkan pengaruh dimensi lainnya seperti harga, tampilan, dan bahan-bahan. Berdasarkan hasil penelitian malalui analisis jalur terdapat pengaruh yang signifikan dari dimensi variasi produk terhadap keputusan pembelian pada pembeli smartphone Nokia series X di BEC Bandung, yaitu 1) ukuran, 2) harga, 3) tampilan, dan 4) bahan-bahan. Pengaruh kedua variabel ini memiliki pengaruh yang signifikan baik secara simultan maupun secara parsial. Penulis merekomendasikan agar perusahaan membuat produk dengan variasi produk secara lebih menarik, sehingga keputusan pembelian meningkat.

Dalam penelitian ini yang berbeda dengan penelitian terdahulu selain lokasi, waktu, data penelitian juga variabel terikat (Y) yaitu keputusan pembelian. Data penelitian terdahulu lebih kesektor elektronik smartphonesebagai objek sedangkan penelitian kali ini lebih ke sektor distribusi produk pada USAHA BENGKEL AHASS PANDAAN. Penelitian ini juga punya kesamaan yaitu menggunakan Variabel bebas (X).

Penelitian terdahulu juga dilakukan oleh Isti Faridisa, Leonardo Budi, dan Maria M. Minarsih yang berjudul Analisis Pengaruh Variasi Produk, Fasilitas, dan Kualitas Pelayanan Terhadap Minat Beli Ulang Konsumen Pada Indonesian Coffeshop Semarang (ICOS Caffe). Penelitian ini bertujuan untuk mengetahui apakah variasi produk, fasilitas, dan kualitas pelayanan berpengaruh terhadap minat beli ulang konsumen di Indonesian Coffeeshop Semarang (I-cos Caffé) dan menganalisis variabel mana yang paling dominan dalam mempengaruhi minat beli ulang konsumen. Dalam penelitian ini, populasi penelitian mengacu pada seluruh konsumen I-cos Café dengan sampel yang diambil sebanyak 96 responden dengan teknik non probability sampling. Berdasarkan hasil penelitian, diperoleh persamaan regresi sebagai berikut : $\mathrm{Y}=-0,687+0,418+$ $0,229+0,470$. Berdasarkan analisis data statistik, indikator-indikator pada penelitian ini bersifat valid dan reliabel. Pada pengujian asumsi klasik, model regresi bebas multikolinieritas, tidak terjadi heteroskedastisitas dan terdistribusi secara normal. Urutan secara individu masing-masing variabel berpengaruh adalah variabel kualitas pelayanan dengan kofisien regresi sebesar 0,47 , diikuti variasi produk dengan regresi sebesar 0,418 dan yang terakhir variabel fasilitas dengan koefisien regresi sebesar 0,229. Model persamaan ini memiliki nilai $\mathrm{F}$ hitung sebesar 46,639 dan dengan tingkat signifikasi sebesar 0,000. Nilai signifikasi ini lebih kecil dari 0,05, hal tersebut menunjukkan bahwa variabel independen dalam penelitian ini berpengaruh secara bersama-sama terhadap variabel dependen yaitu minat beli ulang.Persamaan dari penelitian terdahulu dengan penelitian sekarang yaitu terletak pada X1 yaitu Variasi Produk.

\section{METODE PENELITIAN}

Waktu Penelitian ini dilaksanakan pada awal Bulan Maret 2019 sampai dengan Bulan Mei 2019. Penelitian dilaksanakan di Desa Pandaan, Kecamatan Pandaan, Kabupaten Pasuruan. Lokasi 
penelitian ini merupakan tempat dimana peneliti melakukan penelitian untuk memperoleh data-data yang diperlukan. Adapun penelitian ini dilaksanakan di Bengkel Ahass Pandaan, Kecamatan Pandaan, Kabupaten Pasuruan.

Jenis penelitian yang digunakan dalam penelitian ini yaitu kuantitatif merupakan metode penelitian yang berlandaskan filasafat positif, digunakan untuk meneliti pada populasi atau sampel tertentu, teknik pengambilan sampel pada umumnya dilakukan secara random, pengumpulan data menggunakan instrumen penelitian, analisis data bersifat kuantitatif atau statistik dengan tujuan untuk menguji hipotesis yang telah ditetapkan Sugiyono, 2015:8.

Dalam penelitian ini adalah data Bengkel Ahass Pandaan. Dari rencana penelitian diatas teknik penarikan sampelnya adalah menggunakan insidental sampling yang berdasarkan kebetulan, yaitu siapa saja yang secara kebetulan atau insidental bertemu dengan peneliti dapat digunakan sebagai sampel, bila dipandang orang yang kebetulan ditemui cocok sebagai sumber data.

Adapun teknik pengambilan data dari penelitian ini adalah (a) Observasi menurut Sutrisno hadi (1986) merupakan suatu proses yang kompleks, suatu proses yang tersusun dari berbagai proses biologis dan psikologis. Dua diantaranya yang terpenting adalah proses-proses pengamatan dan ingatan (Sugiyono,2015:145). (b) Kuesioner yang digunakan dalam penelitian adalah kuesioner terbuka yaitu titik pengumpulan data yang dilakukan dengan cara memberi seperangkat pertanyaan tertulis pada responden untuk dijawab (Sugiyono,2015:142). (c) Dokumentasi merupakan catatan kejadian yang sudah lampau yang dinyatakan dalam bentuk lisan, tulisan dan karya bentuk (Satori dan Komariah 2014:148). Operasional variabel adalah hal-hal yang menjadi obyek penelitian yang di tetapkan dalam suatu kegiatan penelitian yang menunjukan variasi atau dapat berubah-ubah baik secara kuantitatif maupun kualitatif (Suharsimi arikunto, 2013;17). Sesuai dengan judul dan pembahasan yang terjadi, maka penulis mendefinisikan tentang variabel yang akan diteliti adalah sebagai berikut :

(a) Variabel Bebas/Independen

Variabel (X) adalah variabel yang mempengaruhi atau menjadi sebab perubahannya atau timbulnya variabel dependen atau terikat. (Sugiyono, $2015: 39$ ) Dalam penelitian ini yang menjadi variabel bebas adalah Variasi Prosuk (X1) dan Tenaga Kerja (X2).Variabel Terikat/Dependen Variabel (Y) adalah variabel yang dipengaruhi atau yang menjadi akibat, karena adanya variabel bebas (Sugiyono, 2015 : 39) Dalam penelitian ini variabel terikat adalah Peningkatan Laba.

Metode analisis yang digunakanadalah Uji Validitas, Uji Reabilitas, Uji Asumsi Klasik, Uji Korelasi Berganda, Uji Regresi Linier Berganda, Uji Koefisien Determinasi, Uji t, Uji F.

\section{HASIL DAN PEMBAHASAN}

Dari pembahasan diatas maka diperoleh hasil sebagai berikut:

Uji Validitas: Hasil uji validitas diperoleh nilai rhituung X1.1 =0,908, X1.2 =0,944, X1.3 = $0,800, \mathrm{X} 1.4=0,936$. rhitung X2.1 =0,967, X2.2 =0,966, X2.3 =0,890, X2.4 = 0,941 rhitung Y1.1 $=0,884, \mathrm{Y} 1.2=0,891, \mathrm{Y} 1.3=0,889, \mathrm{Y} 1.4=0,858$. Berdasarkan uji validitas untuk ketiga variabel bebas $(\mathrm{X})$ dan variabel terikat $(\mathrm{Y})$ diatas diperoleh rhitung> rtabel $(0,300)$, sehingga keseluruhan indikator dari dua variabel tersebut dinyatakan valid

Uji Reliabilitas: Hasil pengujian reliabilitas dengan SPSS metode Alpha Cronbakh'sdiperoleh koefisien alpha pada variabel bebas Variasi produk $\mathrm{X} 1=0,928$. Rhitung $\mathrm{X} 2=$ 0,956 rhitung $\mathrm{Y}=0,885$ lebih besar dari standart reliabilitas $(0,600)$ dengan tingkat signifikasi sehingga dapat disimpulkan bahwa instrument dalam variabel bebas dan terikat adalah reliabel.

Asumsi Klasik :Hasil asumsi klasik terdiri dari :Uji Multikolenieritas, nilai VIF > 10 dan tolerance $>0,1$, maka dapat disimpulkan data terjadi gejala Multikolenieritas. Uji Heteroskedasitas, 
sudah memenuhi syarat bahwa titik-titik menyebar secara acak serta tersebar baik diatas maupun dibawah angka 0 pada sumbu Y. Hal ini dapat disimpulkan bahwa penelitian ini tidak mengandung adanya Heteroskedasitas.Uji Normalitas, memenuhi syarat normal karena penyebaran titik berada disekitar atau mengikuti garis diagonal. Sehingga data diatas dapat dikatakan normal.Nilai DW = 1,924 nilai dengan $(\mathrm{n}=73)$ dan jumlah variabel independen $(\mathrm{k}=2) . \mathrm{Dl}=1,420$ dan $\mathrm{Du}=1,530$. Karena Dw terletak diantara du dan $(4-\mathrm{du})=1,530<1,924<2,470$ maka dapat disimpulkan bahwa tidak bisa menolak H0 (gagal tolak H0) yang artinya tidak ada autokorelasi atau tidak terdapat autokorelasi positif maupun negatif.

Uji Regresi Linier Berganda: Hasil uji regresi linier berganda $\mathrm{Y}=5,083+0,563 \mathrm{X} 1+$ 0,149X2. Maka diketahui besar pengaruh X1 sebesar 0,563 dan X2 sebesar 0,149 dan nilai konstanta sebesar 5,083. Uji Korelasi Berganda: Hasil uji korelasi berganda diperoleh X1 berkorelasi dengan $\mathrm{Y}$ sebesar 0,945 dengan signifikasi 0,000 yang artinya memiliki hubungan sangat kuat dan $\mathrm{X} 2=0,932$ dengan signifikasi 0,000 yang artinya memiliki nilai korelasi searah dan kuat.

Uji Determinasi: Hasil uji determinasi berdasarkan dari data hasil perhitungan analisis regresi pada tabel diatas diperoleh angka R2 (R Square) sebesar 0,894 yang berarti $89,4 \%$. Hal ini menunjukkan bahwa presentase sumbangan pengaruh variabel independen ( Variasi Produk, Tenaga Kerja) terhadap variabel dependen (Peningkatan Laba) atau variabel variabel independen ( Variasi Produk, Tenaga Kerja) mampu mejelaskan sebesar 89,4\% variabel dependen (Peningkatan Laba) . sedangkan sisanya sebesar 10,6\% ditentukan oleh variabel lain diluar variabel penelitian.

Uji t: Berdasarkan hasil uji t parsial yaitu Variasi Produk (X1) Tenaga Kerja (X2), berpengaruh signifikan terhadap Peningkatan Laba Tenaga Kerja (Y), pada Bengkel AHASS Sugio. Dari hasil uji t parsial diperoleh thitung (X1) 4,025 $>\mathrm{t}$ tabel $=2,648$, thitung $(\mathrm{X} 2)=1,063>\mathrm{ttabel}=$ 2,648. Sehingga Ho diterima dan Ha ditolak, yang artinya dari kedua variabel (X) mempunyai pengaruh yang signifikan secara parsial terhadap variabel Peningkatan Laba (Y) pada Bengkel AHASS Panadaan.

Uji F: Berdasarkan koefisien determinasi secara simultan diperoleh Variasi Produk (X1), Tenaga Kerja (X2), berpengaruh signifikasi secara simultan. Hal ini dibuktikan dari hasil Fhitung= 295,001 > Ftabel = 4,92 sehingga Ho ditolak dan Ha diterima, yang artinya variabel Variasi Produk (X1), Tenaga Kerja (X2), mempunyai pemgaruh yang signifikan secara simultan terhadap Peningkatan Laba (Y) pada Bengkel AHASS Pandaan.

\section{KESIMPULAN}

Dari hasil penelitian menunjukkan bahwa variasi produk dan tenaga kerja memiliki pengaruh secara parsial terhadap peningkatan laba pada bengkel Ahass Pandaan, sehingga terjadi pengaruh yang signifikan. Dari hasil penelitian menunjukkan bahwa variasi produk dan tenaga kerja memiliki pengaruh secara Simultan terhadap peningkatan laba pada bengkel Ahass Pandaan, sehingga terjadi pengaruh yang signifikan. Dari hasil regresi linier berganda yang mempengaruhi secara dominan terhadap peningkatan laba pada bengkel Ahass Pandaan adalah variasi produk.

\section{SARAN}

Berdasarkan kesimpulan diatas maka saran-saran yang dapat penulis sampaikan adalah Diharapkan kepada pemilik untuk lebih serius dalam memperhatikan kondisi tenaga kerja dengan memperhatikan kinerja mekanik dalam proses pengerjaan motor konsumen, guna menciptakan tenaga kerja yang handal. Diharapkan kepada perusahaan untuk memperhatikan kualitas barang dan kualitas layanan untuk mencipatakan keseimbangan variasi produk dan pelayanan yang diberikan demi menunjang pendapatan perusahaan. Diharapkan kepada kepala cabang agar mensupply barang 
original secara merata kepada cabang bengkel yang dinaunginya agar nantinya stok barang menjadi sama rata dan dapat diandalkan oleh masyarakat.

\section{DAFTAR PUSTAKA}

Ahyari. 2010. Manajemen pemasaran. Jakarta : PT. Rajawali Pers

Bungin, Burhan M. 2009. Metodologi Penelitian Kuantitatif: Komunikasi, Ekonomi, dan Kebijakan Publik Serta Ilmu-Ilmu Sosial Lainnya. Edisi pertama, Jakarta, Kencana.

Efnita Titik. Pengaruh Variasi Produk, Kualitas Pelayanan, Harga dan LokasiTerhadap Kepuasan Konsumen pada Wedding Organizer. Jurnal Ilmu Manajemen, Volume 12, Nomor 1, Januari 2015

Ferdinand, Augusty. 2006. Metode Penelitian Manajemen. Semarang, Badan Penerbit Universitas Diponegoro.

Faradisa Isti, Leonardo Budi, Maria M Minarsih. Analisis Pengaruh Variasi

Produk, Fasilitas, dan Kualitas Pelayanan Terhadap Minat Beli Ulang Konsumen Pada Indonesian Coffeshop Semarang (ICOS Caffe).Of Management, Volume 2 No.2 Maret 2016

Kotler, Philip \& Kevin, L.K. 2012. Marketing Management. United States of America: Pearson Prentice Hall

Kotler, Philip dan Gary Armstrong. 2008. Prinsip-Prinsip Pemasaran. jilid 2 Jakarta : Erlangga

Kotler, Philip dan Gary Armstrong 2004. Dasar-Dasar Pemasaran. Edisi Kesembilan. Jilid 2

Kotler, Philip. 2000. Manajemen Pemasaran. Jilid 2. Jakarta.Bumi Aksara.

Amaliya, Novita. 2014.Pengaruh Adanya Industri Kerajinan Songkok Terhadap Tingkat Pendapatan Masyarakat Desa Bojoasri Kecamatan Kalitengah Kab. Lamongan.Lamongan. Skripsi. Universitas Islam Lamongan.

Rajagopal. (2007) Impact Radio advertisements on buying behavior of urban commuter. International Journal of Retail \& Distribution Management, Vol.39 Iss: 7 pp. 480 - 503.

Rosdiyati. 2017. Pengaruh Faktor Jumlah Produksi dan Biaya Tenaga Kerja

Terhadap Laba Usaha Telur Asin UD.Sumber Rejeki Desa Tawangrejo Turi Kabupaten Lamongan. Lamongan : Jurnal EKBIS Edisi Maret

Kotler, Philip dan Kevin Keller. 2008. Prinsip-Prinsip Pemasaran. Edisi 12. Jilid pertama

Sugiyono. 2015. Metode Penelitian Kuantitatif, Kualitatif, dan R\&D. Cetakan Ke-22. Bandung. Alfabeta

Sukirno, S. (2001) Pengantar Teori Ekonomi.Jakarta: Raja Grafindo Persada.

Sukirno, S. (2004) Makroekonomi Teori. Pengantar. Jakarta: Raja Grafindo.Persada.

Sukirno, S.2006. Makro Ekonomi Teori Pengantar. Edisi Ketiga. PT. Raja Grafindo Persada, Jakarta.

Suharso, Puguh. 2009. Metode Penelitian Kuantitatif Untuk Bisnis. Jakarta. Indeks

Sumarwan, ujang. 2008. Perilaku Konsumen Teori dan Penerapannya dalam Pemasaran. Jakarta, PT. Gramedia Utama. 
Safitri Lisa, Mona Amelia, Sri Wahyuni. Pengaruh Variasi Produk, Kemasan, Kepercayaan dan Fasilitas Terhadap Keputusan Pembelian Konsumen Pada Oleh-Oleh Kerupuk Jangek Buk Kai di Kota Padang. Jurnal AdBispreneur Vol. 2, No. 2, Agustus 2017

Tanoso, harry. 2011. Majalah Marketing : Galenium. Jakarta Program Hoki. 